\title{
Spatiotemporal variations in channel changes caused by cumulative factors in a meandering river: The lower Peixe River, Brazil
}

\author{
Eduardo S. Morais ${ }^{\mathrm{a}, *}$, Paulo C. Rocha ${ }^{\mathrm{a}}$, Janet Hooke ${ }^{\mathrm{b}}$ \\ a Programa de Pós-Graduação em Geografia, Câmpus de Presidente Prudente, Universidade Estadual Paulista, Presidente Prudente, São Paulo, Brazil \\ b Department of Geography and Planning, School of Environmental Sciences, University of Liverpool, Roxby Building, Liverpool L69 7ZT, United Kingdom
}

\section{A R T I C L E I N F O}

\section{Article history:}

Received 15 January 2016

Received in revised form 15 July 2016

Accepted 17 July 2016

Available online 20 July 2016

\section{Keywords:}

Meandering river

Channel change

Cutoff

Compound meander

Fluvial adjustment

Peixe River

\begin{abstract}
A B S T R A C T
Channel changes in meandering rivers naturally exhibit complex behaviour, and understanding the river dynamics can be challenging in environments also subject to cumulative human impacts. Planform changes were analysed on four reaches of the lower course of the Peixe River, Brazil, at decadal scales over the period 19622008 from aerial photographs and satellite imagery, complemented by a historical map from 1907. Analysis of the spatial and temporal patterns of channel change mechanisms and morphometry of bends and of the sinuosity and morphodynamic variations of the reaches demonstrates major changes in planform characteristics. Sinuosity in all reaches decreased from $\sim 2.6$ to $\sim 1.7$, average wavelength of bends has increased from $\sim 200$ to $\sim 500 \mathrm{~m}$, and the planform has become much simpler. Changes have been progressive from downstream to upstream, with higher intensities of processes, particularly cutoffs first in downstream reaches then more recently in upstream reaches. It is suggested that channel changes represent a morphological adjustment to human interventions, such as reservoir construction and land use. However, evidence of the autogenic behaviour of meanders is highlighted in which the existence of compound meanders reveals control over the spatial variation in the reaches. The results suggest that geomorphic thresholds associated with the compound meander formation and the bend evolution should be considered, even in impacted meandering rivers, because they exert primary controls on the spatial-temporal adjustment of channels.
\end{abstract}

(C) 2016 Elsevier B.V. All rights reserved.

\section{Introduction}

Meandering rivers may behave as highly dynamic geomorphic systems. Channel changes in these rivers in natural environments exhibit complex interactions in floodplains and are frequently regulated by a dynamic state of bend evolution and self organization (Stølum, 1996; Hooke, 2004; Gautier et al., 2010). Human activities cause changes in discharge regime and sediment flux leading to morphological adjustments. Several human interventions are responsible for producing hydrological changes that result in fluvial adjustment in river channels (Gregory, 2006), including removal of forest cover, mining, reservoirs, forestry, agriculture, and urbanization. These can produce changes in the width, depth, sinuosity, or channel stability of a river (Sherrard and Erskine, 1991; Brandt, 2000; Rinaldi, 2003; Ziliani and Surian, 2012; Montanher, 2013; Bollati et al., 2014). In some cases this has led to the loss of fluvial dynamics in active meandering rivers (greater stability; Magdaleno and Fernández-Yuste, 2011). Therefore, significant interest lies in understanding changes in fluvial dynamics because of their

\footnotetext{
* Corresponding author.

E-mail address: msedu.geo@gmail.com (E.S. Morais).
}

value to biodiversity, urban and rural planning, and environmental management.

Recently, studies have promoted an interesting discussion about the behaviour of meandering rivers induced by environmental disturbances. Ollero (2010) showed that the dynamics of cutoffs and the consequent creation of oxbow lakes on the Ebro River, Spain, were sensitive to urbanization and agriculture; the channel mobility was suppressed, which stabilized the channel. Moreover, Phillips (2003) observed channel changes downstream of a reservoir in a meandering river of Texas, USA, and was able to identify a limited impact on the fluvial behaviour. In addition, Heitmuller (2014) studied the same river in Texas and documented reservoir-induced aggradation effects that led to the stabilization of marginal deposits and the successive colonization of vegetation.

In Brazil, particularly in the Amazon, meandering rivers were the basis of elucidating the self-organized state (Stølum, 1998). The autogenic behaviour of meandering rivers in the tributaries of the Amazon River was also highlighted recently, where the channels with the largest sediment loads were found to be more dynamic and to have higher migration and cutoff rates (Constantine et al., 2014). In northeastern Brazil, the characteristics of a fluvial adjustment downstream of a reservoir was related to the formation of meanders (Souza and Corrêa, 2012), 
similar to the classic study on adjustments by Sherrard and Erskine (1991).

Dynamics of tropical and subtropical rivers are much less well understood than those of temperate regions. Southeast Brazil forms part of the drainage of the Paraná River, one of the largest rivers in the world, and is a region that has been subject to extensive and ongoing land use and river management changes. In southeastern Brazil, especially in the upper Paraná River basin, most tributaries exhibit a meandering pattern in their lower courses. These meandering rivers may be bedrock with occasional channel changes, such as the Grande, Piquiri, and Ivaí rivers, or alluvial with more frequent channel changes, such as the Aguapeí, Corumbataí, and Atibaia rivers. In the latter set of rivers, Cândido (1971) argued that the morphometric variables are important indicators of the development of the channel pattern. Extrinsic factors were also addressed by Zancopé and Perez Filho (2006); Zancopé et al. (2009), who attributed the morphometric variations in the meanders in different geomorphological segments of the Mogi Guaçu base levels along the channel associated with tectonic factors.

The channel of the Peixe River, a tributary of the Paraná River located in the state of São Paulo, exhibits a typical meandering pattern in its lower course. The presence of hundreds of paleochannels and oxbow lakes in the floodplain with up to two levels of adjacent terraces suggests intense fluvial dynamics during the Quaternary. Additionally, the catchment of the Peixe River has been subject to human disturbance over the last 90 years. In this study the aims are (i) to identify the spatial and temporal patterns of planform changes and their variations in different reaches of the lower Peixe River, (ii) to analyse the scale, types, and mechanisms of change in meander morphology; and (iii) to investigate the possible explanations of changes in form, especially the extent of adjustment to human activities and the influence of autogenic processes. Studies at the reach scale have provided important insights in cases of adjustment (Ziliani and Surian, 2012; Downs et al., 2013; Bollati et al., 2014). Here, this study attempts to contribute to the understanding of meandering rivers subject to cumulative factors in tropical regions.

\section{Study area}

The Peixe River catchment is located in the western part of São Paulo State with a total area of $10,769 \mathrm{~km}^{2}$ (Fig. 1). The main channel is $380 \mathrm{~km}$ long from the sources in Agudo Mountain, Marília City, at an elevation of $670 \mathrm{~m}$ approximately, to the mouth of the Paraná River, at an elevation of $265 \mathrm{~m}$ approximately. The predominant lithology is Cretaceous (K) sandstone belonging to the Bauru Group, which comprises an extensive portion of the sedimentary basin of the Paraná River. Variations in the sand granulometry and depositional environment subdivide the Bauru Group in the Peixe River catchment into three sedimentary formations. These rocks are composed of fine to coarse sand, and intercalations of mud layers increase in these deposits toward the Paraná River (Fernandes and Coimbra, 2000; Perrota et al., 2005).

The geomorphology of the slopes in the catchment was summarized by Etchebehere (2000). The highest areas (650-750 m) correspond to the Plateau Marília (Ross and Moroz, 1996; Santos et al., 2013), characterized by dissected relief with craggy borders. The remaining portions include intermediate elevations (650-280 m), which feature wide and convex slopes with flat tops.

The reaches analysed in this study are located in a 70-km section along the lower course of the Peixe River (Fig. 1), where the channel is reworking alluvial sediments and exhibiting a sinuous morphology. In this segment, the alluvial valley becomes prominent and features a wide floodplain (400-3400 m) flanked by Holocene terraces. Sedimentation on the floodplain created salient levees formed by a fining upward from sand to mud. On the banks, the riparian vegetation is formed mostly of trees and secondarily of shrubs, characterized by species such as Nectandra megapotamica, Ficus insipida, and Syagrus
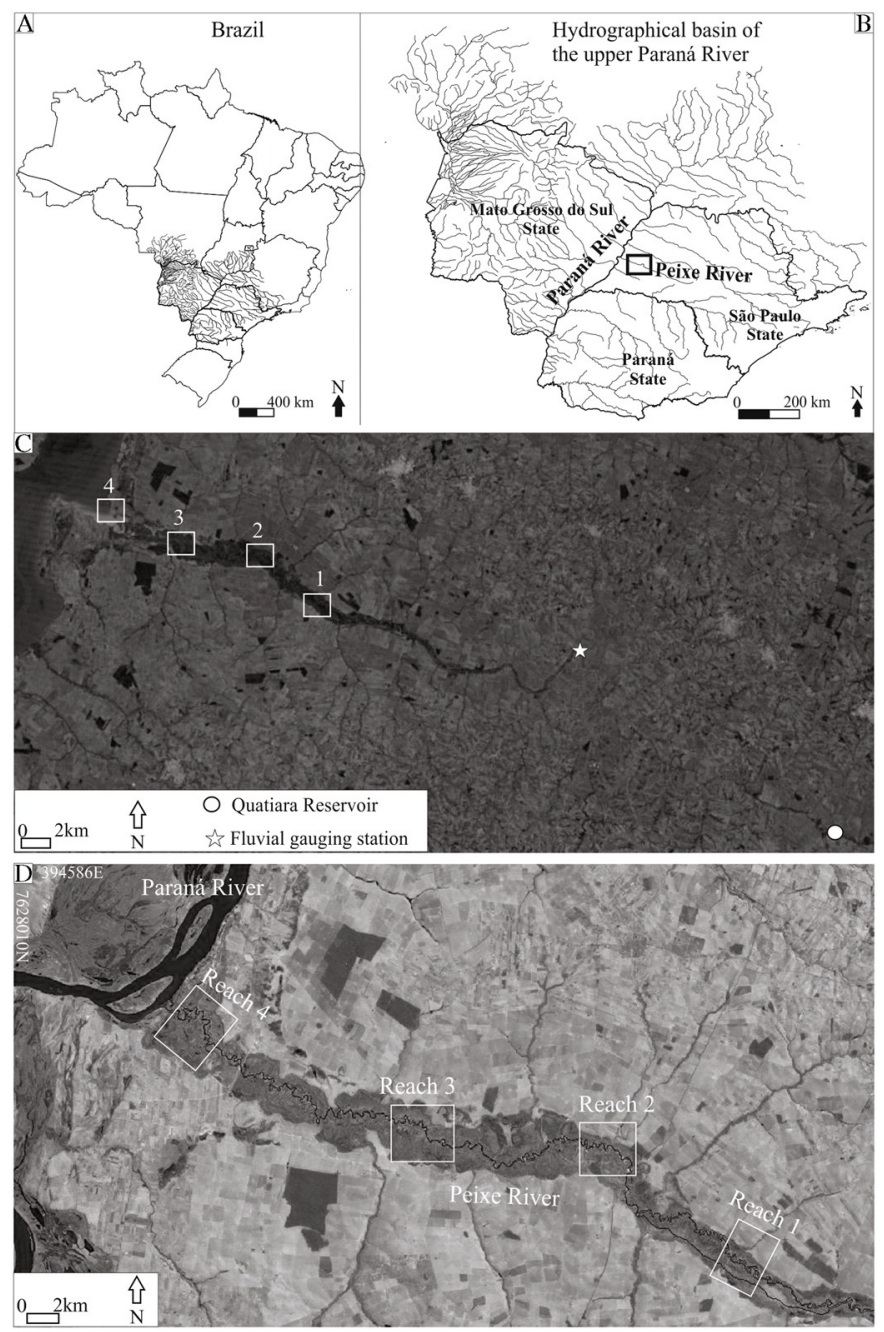

Fig. 1. (A) The Peixe River is located in Brazil and (B) is part of the hydrographic network of the upper Paraná River basin. (C) The reaches located in the alluvial valley along the lower course of the Peixe River, and the fluvial gauging station and reservoir in the upstream section. (D) In the 1995 Landsat image, reach 4 is shown before inundation from a reservoir downstream in the Paraná River in 1998.

romanzoffiana, while toward distal parts of the floodplain, in backswamp and oxbow-lakes, occur a diversity of macrophytes, such as Eichornea crassipes, Nymphea sp., and Ludwigia sp. (SMAESP, 2010).

Four reaches have been selected for comparison and analysis of the spatial patterns (Fig. 1). These are $\sim 4 \mathrm{~km}$ long and $\sim 8 \mathrm{~km}$ apart and were chosen based on aerial photograph availability and the potential to register channel changes. The catchment area at the upstream reach (reach 1) has $8466 \mathrm{~km}^{2}$ (79\% of total area), while the downstream reach (reach 4$)$ includes all catchment area $\left(10,769 \mathrm{~km}^{2}\right)$. The current channel width in the reaches ranges between 30 and $80 \mathrm{~m}$; and floodplain average widths in reaches $1,2,3$, and 4 are $1.42,1.91,1.69$, and $1.62 \mathrm{~km}$, respectively.

\subsection{Climate and hydrological regime}

The climate of the Peixe River catchment has two distinct periods: a warm and rainy period between October and March and a more mild and dry period from April to September. The average annual rainfall in the region is $1300 \mathrm{~mm}$, with annual variability of up to 50\% (Santa'nna Neto and Tommaselli, 2009). In the vicinity of the municipalities of Ouro Verde and Presidente Venceslau, $30 \mathrm{~km}$ upstream from the mouth, the sediment transport in suspension has an average 
concentration of $7.81 \mathrm{mg} / \mathrm{l}$, whereas bedload is characterized mainly by fine sand (Santos, 2013).

The characteristics of the hydrological regime of the Peixe River were assessed with daily flow data between the years 1976 and 2013 (Fig. 2A). These data are from the Florida Paulista gauge station (63805000 code; Fig. 1C), $50 \mathrm{~km}$ downstream from the Quatiara reservoir and $45 \mathrm{~km}$ upstream of the beginning of reach 1 , and were provided by CESP (São Paulo Energy Company).

The discharge in the Peixe River exhibits a wide variation, with $\mathrm{Q}_{\text {minimum }}=9.20 \mathrm{~m}^{3} / \mathrm{s}, \mathrm{Q}_{\text {maximum }}=816.50 \mathrm{~m}^{3} / \mathrm{s}$, and $\mathrm{Q}_{\text {average }}=$ $63.40 \mathrm{~m}^{3} / \mathrm{s}$, and the hydrological regime matches the distribution of rainfall in the region. Floods occur at least once a year in the Peixe River as identified by discharge higher than bankfull level, which was adopted from an overflight of photos taken on a day of initial flooding along the floodplain. The annual maximum flows indicate a pronounced oscillation (Fig. 2A), with flows from just above the bankfull discharge to flows six times that of bankfull events $\left(135.8-816.5 \mathrm{~m}^{3} / \mathrm{s}\right)$.

Floods in the Peixe River have durations of 20 days each year approximately, based on a wide range of recorded events (Fig. 2B). The full wave lasts from 1 day to 60 days. The majority of days with bankfull flow (80\%) occur between December and March (Fig. 2C), which corresponds to the rainy season. The months of January and February particularly are responsible for $55 \%$ of this concentration of floods. In addition, significant decrease of flow exists between the months of April and November, which corresponds to the drought that affects the Peixe River catchment during the winter. However, rare sporadic flood events do occur in this period.

\subsection{Anthropogenic factors}

Changes in land use and reservoir construction constitute the main activities that potentially impact the fluvial dynamics in the Peixe
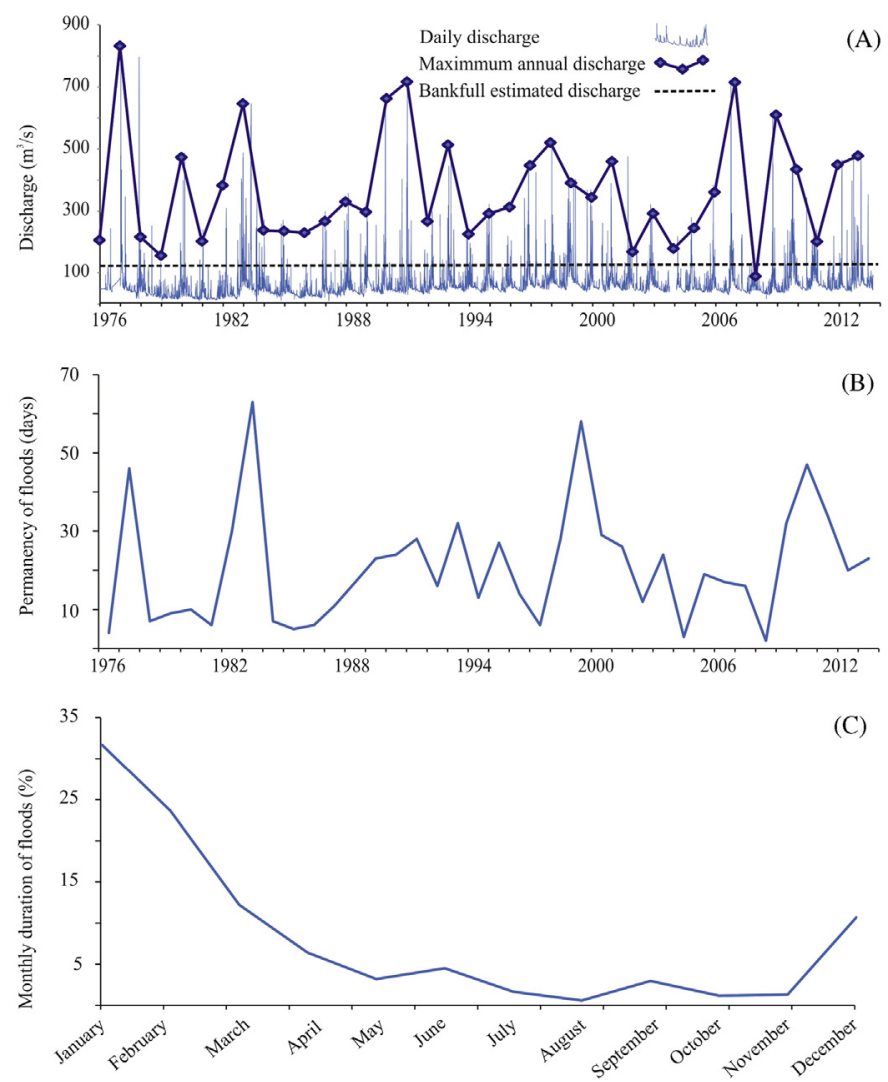

Fig. 2. (A) Daily discharge between 1976 and 2013, with the estimated bankfull value and annual maximum discharge; (B) persistence of floods (days) over years; and (C) persistence of floods (\%) over months.
Table 1

Changes in land use and occupation in the catchment of the Peixe River. Adapted from Chiarini et al. (1976), CBH-AP (2008), and Trivellato and Perez Filho (2012).

\begin{tabular}{llll}
\hline Land use classes (\%) & 1972 & 1997 & 2008 \\
\hline Pasture & 65 & 71 & 67 \\
Temporary culture (sugarcane and cotton) & 21 & 11 & 24 \\
Permanent culture (coffee and others) & 4 & 2 & 2 \\
Forest & 10 & 16 & 7 \\
\hline
\end{tabular}

River through responses to hydrological and sediment load modifications. The occupation of western São Paulo, where the catchment area of the Peixe River is located, has intensified since the 1920s. However, economic situations and soil depletion drove different production cycles in the basin over the decades. In addition to the increase in agriculture, 27 cities developed and the population increased by 52\% from 460,818 to 703,361 inhabitants between 1980 and 2010 (CBH-AP, 2008).

Chiarini et al. (1976), CBH-AP (2008), and Trivellato and Perez Filho (2012) summarized recent changes in land use in the catchment of the Peixe River (Table 1). Four phases of changes in land use are generally identified. Initially, with the expansion of Brazilian agriculture in the mid-1910s, the forest in the hydrographic basin was thinned because of coffee planting, which occurred concurrently with the inclusion of extensive livestock areas with low agricultural productivity.

As an alternative to coffee cultivation, cotton planting has gradually increased since 1945. Owing to the climatic conditions and depleted soil, the predominant agriculture was replaced by extensive livestock in the 1960s. Finally, in the early 1990s, the regional economic production arrangement fostered the return of agriculture in the catchment with the planting of sugarcane (Brannstrom and Oliveira, 2000).

As a result of these changes in land use, certain processes shaped the landscape of the catchment, such as erosion on the slopes, where 89 and 684 gullies in urban (documented in 1984) and rural (documented in 1987) areas, respectively (CBH-AP, 1997), were catalogued. These erosive processes are potential sources of sediment, which can partially be stored in the plains or along the Peixe River.

The alluvial fans in the Peixe River valley and along its tributaries are indicative of the intensity of erosion in the catchment. The formation of these geomorphic units marks historical land use in this catchment and has been reported as an indicator of erosion that occurred caused by changes in land use along the Peixe River (Brannstrom and Oliveira, 2000; Etchebehere and Saad, 2003). In the alluvial valley of the lower course, where the reaches in this study are located, eight of these geomorphic units have significant sizes ( 0.4 to $42.7 \mathrm{ha}$ ) and active depositional dynamics. Additionally, a preliminary analysis of middle and upper segments of the Peixe River indicated decreasing sinuosity between 1907 and 1974 and the disappearance of at least seven riffles and increasing channel width between 1907 and 2012, interpreted as channel changes related to anthropogenic factors (Trivellato, 2013).

Reservoirs of hydroelectric power plants located on the Peixe and Paraná rivers are also considered anthropogenic factors that potentially influence river dynamics. The small hydroelectric power plant Quatiara (Fig. 3) was installed upstream of the study reaches between 1939 and 1947, flooding an area of $0,93 \mathrm{~km}^{2}$ and having a generating capacity of $2 \mathrm{MW}$. The enterprise is located in the city of Rancharia, $40 \mathrm{~km}$ upstream from reach 1 . The operating characteristics of the reservoir allow accumulated sediment to be periodically released downstream. During the rainy season, i.e., spring and summer, the spillway is opened two or three times a week; whereas during the dry season, i.e., autumn and winter, the spillway is opened once a week. With the release of sediment plumes through the spillway (Fig. 3B), the sediment in the Peixe River forms deposits on the bedrock channel with tens of meters length (Fig. 3D).

The other reservoir that influences the Peixe River is located on the Paraná River downstream of the reaches, where impoundment in the year 1998 created a backwater at the confluence of the two rivers. 

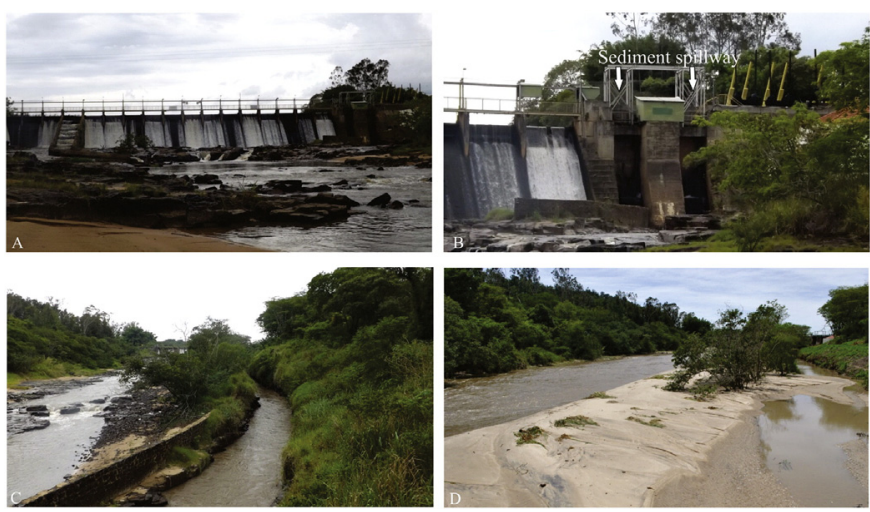

Fig. 3. (A) View of Quatiara hydroelectric, located upstream of the reaches, (B) view of the dam showing the sediment spillway, (C) channel downstream of the dam, and (D) volume of sediments mobilized by the opening of the spillway.

(Available from http://www.nossalucelia.com.br/n7745.html.)

This reservoir flooded $4 \mathrm{~km}$ upstream from the mouth of the Peixe River, including reach 4 in this study (Fig. 1A-B), with a backwater that extends over $8 \mathrm{~km}$ upstream. Some of the implications of this reservoir on the Paraná River are known (Martins et al., 2009; Souza Filho, 2009; Rocha, 2010), but the possible impacts of the reservoir on the upstream tributaries, such as the Peixe River, are unknown.

\section{Methodology}

The study was performed in four selected reaches along the alluvial valley in the lower course of the Peixe River using aerial photographs and satellite images to assess channel changes in the periods of 1962 1978, 1978-1997, and 1997-2008, totalling 46 years of analysis. A historical map from 1907 was also used to measure the forms and interpret the characteristics of the meanders in the environment prior to major human settlement and development. The historical map from 1907 has a scale that prevents a quantitative comparison (Table 2) and was made by an expedition of naturalists from the Brazilian Geographic and Geological Commission in a preliminary occupation period in the region (CCG, 1913).

The images were manipulated in the geographic information systems SPRING 5.3 (Câmara et al., 1996) and QGis 2.8.2-Wien (QGIS Development Team, 2016). To minimize the georeferencing errors, only individual aerial photographs were used to avoid the construction of mosaics. Errors between 0.92 and $3.57 \mathrm{~m}(<10 \%$ of width in all sections and much less along most of the course) do not interfere with the interpretation of the results and are similar to those present in studies using a similar approach (Gilvear et al., 2000; Winterbottom, 2000). In the aerial photographs and images, the channel margins in each reach were digitalized for each date. Meanders were recognized by visual interpretation of the inflection points formed from the planform curvature and were numbered from upstream to downstream.

The methods applied to the channel change investigation are summarized in Table 3. For each reach, sinuosity was measured at each

Table 2

Aerial photographs and images used for the analysis of the spatial and temporal variations in the channel.

\begin{tabular}{lll}
\hline Material & Year & Scale \\
\hline Map & 1907 & $1: 50,000$ \\
Aerial photograph & 1962 & $1: 25,000$ \\
Aerial photograph & 1978 & $1: 20,000$ \\
Aerial photograph & 1997 & $1: 35,000$ \\
CBERS 2/HRC image & 2008 & $1: 13,500$ \\
\hline
\end{tabular}

Table 3

Set of procedures applied to investigate the channel changes in the Peixe River.

\begin{tabular}{ll}
\hline Methods & Parameters \\
\hline Morphology & Mechanisms of channel change in meanders \\
& Reach activity rate through mechanisms of channel change \\
Morphometry & Sinuosity \\
& Amplitude \\
& Wavelength \\
Morphodynamics & Measure of eroded and deposited areas, and its variations \\
Integrated analysis & Factor analysis \\
\hline
\end{tabular}

date. The activity rate of each reach for each period was determined by the percentage of meanders that exhibited channel changes in each period. Channel change was defined as movement of the bank line by $>10 \mathrm{~m}$. Within each reach for each period the mechanisms of bend change were identified, and the morphometric changes in bends and the morphodynamics of erosion and deposition areas were measured as follows.

\subsection{Morphology}

The mechanisms of channel changes in the meanders in each reach for each period were classified according to Hooke and Harvey (1983) and included the following types: growth, migration, confined migration, lobing, double heading, cutoff, retraction, new meander, and complex change (Fig. 4). Stable meanders were also counted and avulsion was added as a channel change mechanism. The numbers of each type in each period were recorded. The transformations on compound meanders were observed and their implications associated for fluvial adjustment mechanisms considered.

\subsection{Morphometry}

The changes in reaches were evaluated according to the variations in the morphometric parameter of sinuosity, and individual meanders were analysed for their wavelength and amplitude (Fig. 5). The procedure used to evaluate the wavelength and amplitude is similar to that

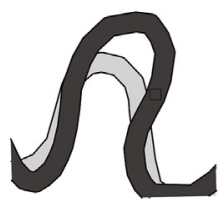

Growth

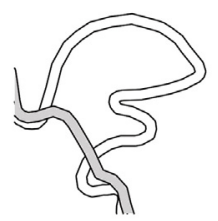

Cutoff

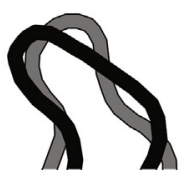

Double-heading

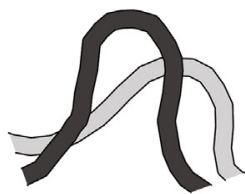

Migration

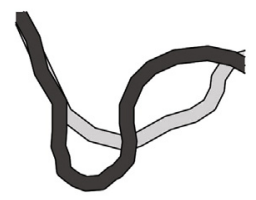

New Meander

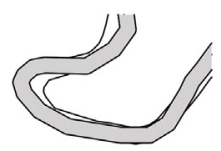

Lobing

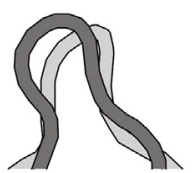

Confined Migration

$$
\square 1962 \square 1978 \square 1997 \square 2008 \quad<\text { Flow }
$$

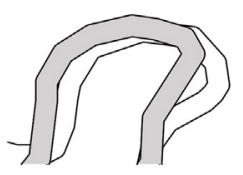

Retraction

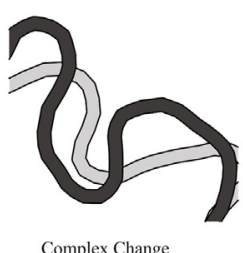

Fig. 4. Channel change mechanisms found in the Peixe River, classified according to Hooke and Harvey (1983). 


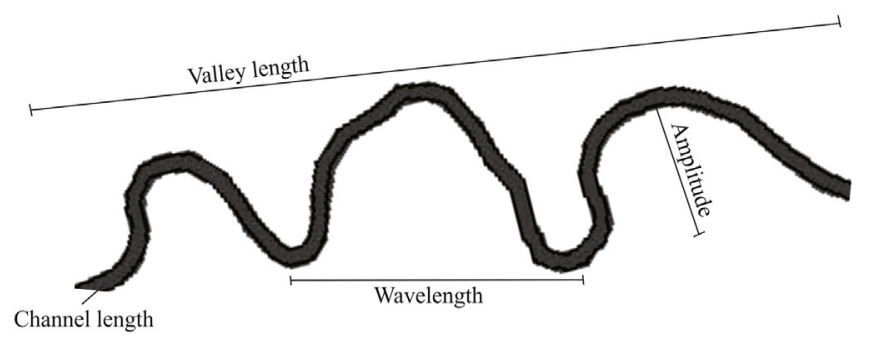

Fig. 5. Sinuosity, wavelength, and amplitude as measured on the meanders in the Peixe River.

used by Magdaleno and Fernández-Yuste (2011). We use the analysis of variance of each variable for each reach at each date.

Initially, the normal distributions of wavelength and amplitude of each group at different dates (for example, the amplitude of the meanders in reach 1 in 1962 and 1978) were compared at a significance level of $\alpha=0.05$ with the Kolmogorov-Smirnov test. Owing to the rejection of the normal distribution and because the number of variances for the groups differed, the statistical analysis was addressed using a nonparametric method. The analysis between two groups used the WilcoxonMann-Whitney test with a significance level of $\alpha=0.05$ to indicate significant variation in the morphometric parameter. Statistical tests of these morphometric parameters were analysed to highlight the spatial variations in significant changes between reaches.

\subsection{Morphodynamics}

The measurement of morphodynamics refers to calculation of the floodplain areas reworked $\left(\mathrm{m}^{2}\right)$ by the channel. The analysis was based on Hooke and Yorke (2010) with area differences through channel vector position between the years. Eroded area $(E)$, deposited area $(D)$, and area formed by both processes $(A P)$ were mapped along all reaches. This last parameter comprises, for example, in case of cutoff or avulsion, the central portion of floodplain between deposited area (paleochannel) and eroded area (new course). In addition to these parameters, the total eroded and deposited areas $(T)$ and the ratio of eroded and deposited areas $(E / D)$ were calculated. These values are used to analyse spatial and temporal variations in the intensity of processes involved in channel changes and affecting the floodplain.

\subsection{Factor analysis}

An integrated evaluation of the morphometry, change mechanisms in the meanders, and morphodynamics was performed with a factor analysis, which involved a method to extract the principal components. The data were normalized, and the previous analysis of the commonalities and correlations indicated the need to exclude the amplitude, wavelength, and channel change mechanisms. In total, the following six variables were analysed: sinuosity, activity rate, eroded area, deposited area, ratio of eroded and deposited areas, and total eroded and deposited areas.
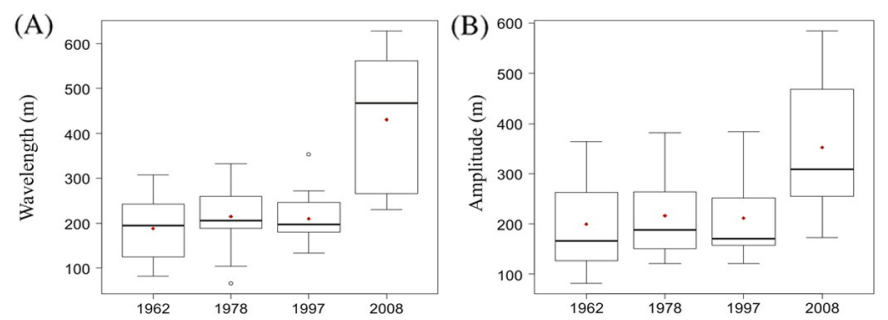

Fig. 6. The variation in the wavelength (A) and amplitude (B) in reach 1.
Table 4

Channel change mechanisms that occurred in the meanders (\%) in reach 1.

\begin{tabular}{llll}
\hline Channel change & $1962-1978$ & $1978-1997$ & $1997-2008$ \\
\hline Migration & 11 & 17 & 19 \\
Confined migration & 11 & 9 & 0 \\
Growth & 6 & 9 & 13 \\
Lobing & 6 & 0 & 6 \\
Double-heading & 0 & 4 & 0 \\
New meanders & 0 & 4 & 0 \\
Retraction & 0 & 22 & 12 \\
Cutoff & 8 & 17 & 50 \\
Complex changes & 0 & 4 & 0 \\
Stable meanders & 58 & 14 & 0 \\
\hline
\end{tabular}

\section{Results}

The historic map from 1907 revealed high sinuosity (2.22-2.76) in all reaches in this year. The types of bend were evaluated, and the presence of compound meanders was identified only in reaches 1 and 4 (upstream and downstream, respectively), comprising $20 \%$ of each reach, approximately. Despite the interval of 55 years until the next record in 1962, we identified the occurrence of channel change mechanisms, such as cutoff and migration, and noted the formation of new meanders in the previously straight segments.

\subsection{Temporal dynamics}

The evolution of each reach for each time epoch in the study period (1962-2008), 1962-1978, 1978-1997, and 1997-2008, is described individually to highlight the differences in the channel's behaviour.

\subsubsection{Reach 1}

Reach 1 experienced the smallest changes in its morphology during 1962-1978 (Fig. 6; Tables 4-6). Mechanisms with different responses to the channel's morphology, such as migration and cutoffs (Fig. 7A), resulted in a balanced sinuosity for the reach, as seen in the slight decline of $0.4 \%$ in the sinuosity between 1962 and 1978 (Table 4). Minor changes in the channel's behaviour in this period are also corroborated by the smaller total morphodynamics than next periods (Table 5).

From 1978 to 1997, the channel changes in reach 1 became more distributed and pronounced than in the previous period (Fig. 6; Tables 4-6). These abandonments also contributed to a higher reworking of the channel in the floodplain, highlighted by the increase in deposited areas (Table 5). The morphology of the reach became less sinuous in 1997, with the high decrease in sinuosity in this period (Table 6).

Table 5

Morphodynamic annual values $\left(10^{3} \mathrm{~m}^{2}\right)$ to each period in reach 1 .

\begin{tabular}{llllll}
\hline Period & $E$ & $D$ & $A P$ & $T$ & $E / D$ \\
\hline $1962-1978$ & 0,64 & 0,68 & 0,04 & 1,35 & 0,93 \\
$1978-1997$ & 0,63 & 0,76 & 0,19 & 1,57 & 0,82 \\
$1997-2008$ & 0,76 & 1,15 & 0,21 & 2,12 & 0,66 \\
\hline
\end{tabular}

$E=$ eroded area, $D=$ deposited area, $A P=$ area formed by both processes, $T=$ total morphodynamics, and $E / D=$ ratio of eroded and deposited areas.

Table 6

Sinuosity and number of bends in reach 1 .

\begin{tabular}{lllll}
\hline & 1962 & 1978 & 1997 & 2008 \\
\hline Sinuosity & 2.82 & 2.80 & 2.43 & 1.84 \\
Number of bends & 23 & 21 & 17 & 10 \\
\hline
\end{tabular}



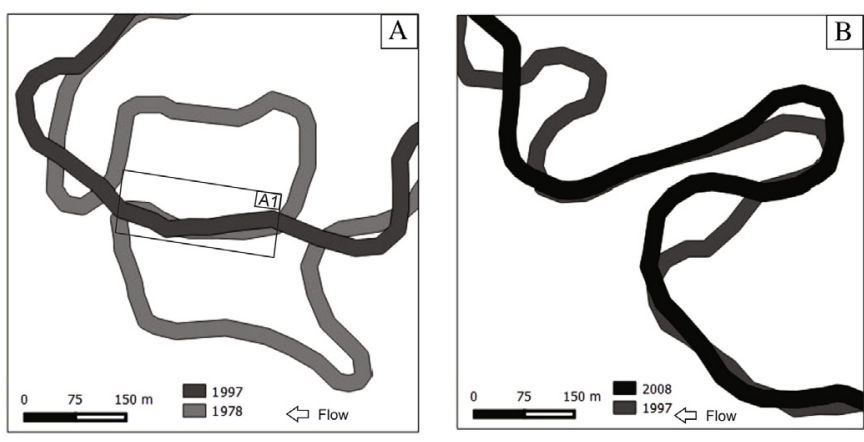

Fig. 7. (A) Example of complex cutoffs involving channel reoccupation but with the flow in the opposite direction in one portion, A1; (B) the growth of the meander example and the characteristic narrowing preceding neck cutoff formation, along with a cutoff in a meander with lower amplitude.

The flow channel of Peixe River during this period divided upstream from reach 1, resulting in the formation of a secondary channel (Fig. 8). This secondary channel was formed from an avulsion process and became established as a part of the current drainage network. This channel was $14.5 \mathrm{~km}$ long and reconnected to the main channel downstream of reach 1 and upstream of reach 2 .

In the last period, 1997-2008, reach 1 experienced the greatest changes in its morphology (Fig. 6; Tables 4-6). Furthermore, the strong dynamics of the reach in this period can be confirmed by cutoffs, besides the remarkable proportion of migration and growth in the meanders (Fig. 7B). The intense dynamics in this period (Table 4) is reinforced by higher total amount of reworked areas in the floodplains than that found for the previous periods (Table 5). The channel changes in this reach resulted in the highest reduction in the sinuosity during this period.

\subsubsection{Reach 2}

The channel changes in reach 2 during 1962-1978 produced large transformations in the morphology (Fig. 9; Tables 7-9) that were mainly owing to the development of cutoffs (Table 7). Furthermore, the higher sedimentation rates in this period (Table 7) mainly reflect the effects of cutoffs. Reach 2 in this period decreased its sinuosity by $17.8 \%$ (Table 9).

Channel changes produced the greatest transformation in the morphology of reach 2 from 1978 to 1997 (Fig. 9; Tables 7-9). Despite the decrease in cutoffs compared to the previous period, the occurrence of this mechanism in meanders with larger amplitudes was vital to the strongest transformation of morphology (Fig. 10A). These variations in

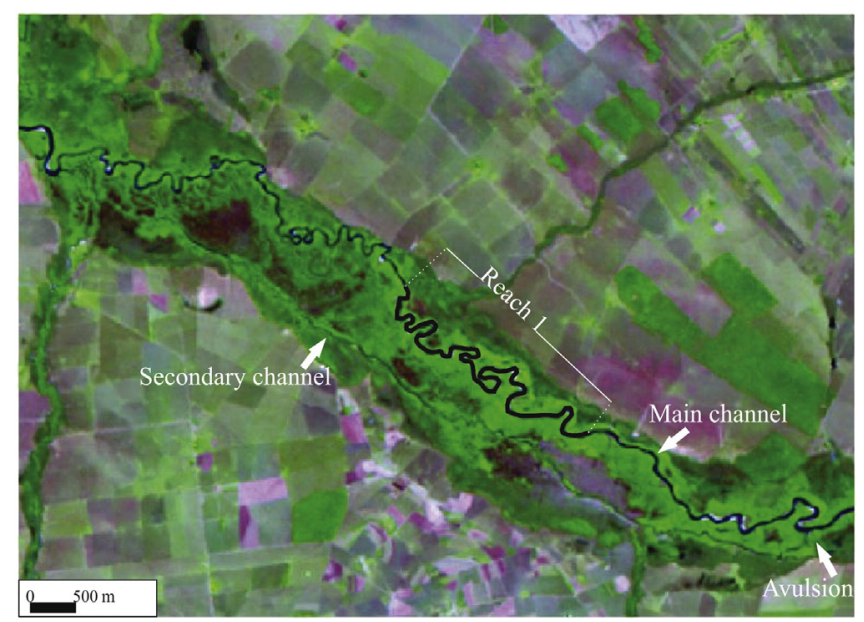

Fig. 8. Landsat 5 image from 1985 that shows the secondary channel as a part of the drainage network
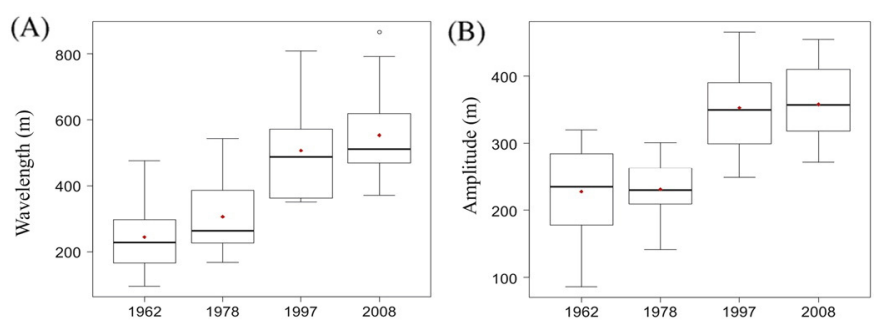

Fig. 9. The variation in the wavelength (A) and amplitude (B) in reach 2; the morphometric parameters indicate a marked change between 1978 and 1997.

the average amplitude and wavelength of the meanders also reinforced the intensity of the changes in this period.

The channel in this reach reworked the floodplain (Table 8), leading to an increase in eroded areas and areas created by erosion and by deposition. The sinuosity decreased in 1997 (10.1\%), primarily because of cutoffs, similar to the previous period (Table 9 ).

The changes in reach 2's morphology during the period 1997-2008 were very slight (Fig. 9; Tables 7-9), with a marked reduction in change mechanisms compared to the other periods. The prevalent changes included growth and migration (Fig. 10B; Table 7), which increased the amplitude and wavelength, respectively. During this period, a greater equivalence coefficient existed between the eroded and deposited areas (Table 8 ) and sinuosity increased slightly (Table 9). The change mechanisms in this period, with the dominance of migration and growth and the absence of cutoffs, suggest the development of meanders; and the morphodynamic values indicate the low remobilization of materials in the floodplain in reach 2 (Table 8 ).

\subsubsection{Reach 3}

The greatest changes in the morphology of reach 3 occurred during the period 1962-1978 (Fig. 11; Tables 10-12), primarily owing to the strong combination of cutoffs (Fig. 11) and avulsions (Table 10). The

Table 7

Channel change mechanisms that occurred in the meanders (\%) in reach 2.

\begin{tabular}{llll}
\hline Channel change & $1962-1978$ & $1978-1997$ & $1997-2008$ \\
\hline Migration & 9 & 11 & 12 \\
Confined migration & 0 & 6 & 0 \\
Growth & 26 & 6 & 12 \\
Lobing & 4 & 6 & 0 \\
Double-heading & 0 & 0 & 0 \\
New meanders & 0 & 11 & 0 \\
Retraction & 4 & 11 & 7 \\
Cutoff & 35 & 32 & 0 \\
Complex changes & 3 & 6 & 0 \\
Stable meanders & 17 & 11 & 69 \\
\hline
\end{tabular}

Table 8

Morphodynamic annual values $\left(10^{3} \mathrm{~m}^{2}\right)$ to each period in reach 2 .

\begin{tabular}{llllll}
\hline Period & $E$ & $D$ & $A P$ & $T$ & $E / D$ \\
\hline $1962-1978$ & 0,89 & 1,24 & 0,06 & 2,17 & 0,72 \\
$1978-1997$ & 0,60 & 0,74 & 0,30 & 1,63 & 0,81 \\
$1997-2008$ & 0,87 & 0,83 & 0,19 & 1,89 & 1,05 \\
\hline
\end{tabular}

$E=$ eroded area, $D=$ deposited area, $A P=$ area formed by both processes, $T=$ total morphodynamics, and $E / D=$ ratio of eroded and deposited areas.

Table 9

Sinuosity and number of bends in reach 2 .

\begin{tabular}{lllll}
\hline & 1962 & 1978 & 1997 & 2008 \\
\hline Sinuosity & 2.30 & 1.89 & 1.61 & 1.65 \\
Number of bends & 27 & 19 & 14 & 14 \\
\hline
\end{tabular}




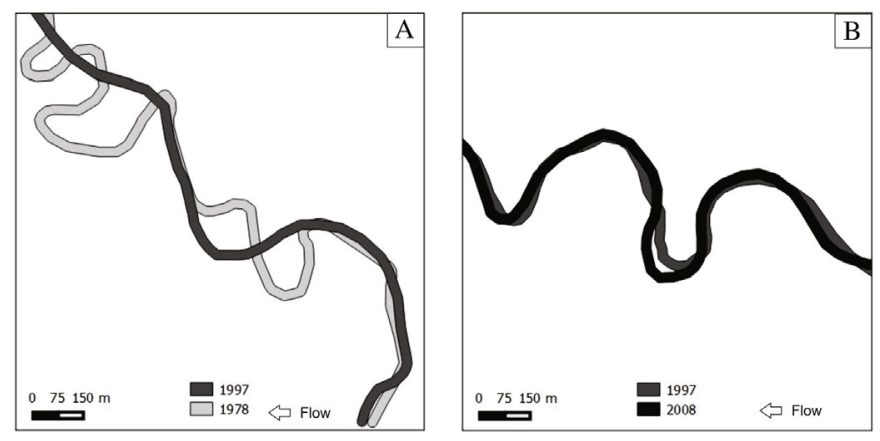

Fig. 10. (A) Example of drastic reduction in meanders that produced a simplified channel morphology, and (B) slight growth in the remaining meanders.
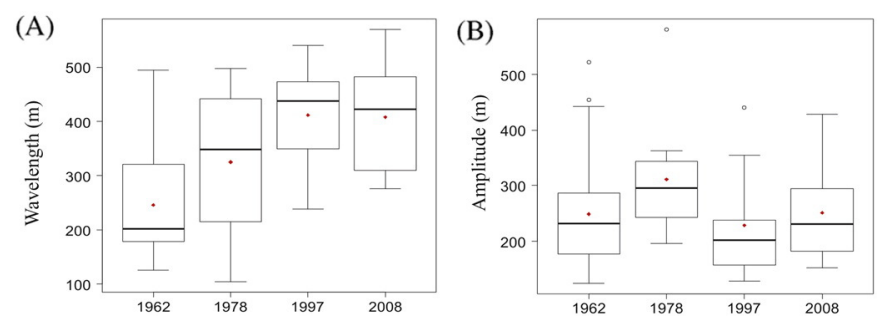

Fig. 11. The variations in the wavelength (A) and amplitude (B) in reach 3.

morphodynamics of reach 3 during this period resulted in high remobilization rates for the floodplain channel, generating similar eroded and deposited areas (Table 11). The sinuosity decreased by $21.7 \%$ because of cutoffs and avulsions (Fig. 12A) and was not greater because erosion occurred alongside growth and migration in the meanders (Table 12).

Avulsions occurred in reach 3 (Fig. 12; Table 10). The first avulsion occurred prior to 1962 , forming a 580 -m-long channel that carried flow until 1978 (Fig. 12B-D). The second occurrence was in the period 1962-1978 and extended $1.5 \mathrm{~km}$ (Fig. 12E-G). Seven cutoffs were observed in the multichannel segment prior to the second avulsion.

The avulsions created ephemeral multichannel segments and caused large areas to become abandoned in 1997, resulting in the

Table 10

Channel change mechanisms that occurred in the meanders (\%) in reach 3.

\begin{tabular}{llll}
\hline Channel change & $1962-1978$ & $1978-1997$ & $1997-2008$ \\
\hline Migration & 6 & 9 & 13 \\
Confined migration & 0 & 9 & 6 \\
Growth & 11 & 9 & 18 \\
Lobing & 0 & 0 & 13 \\
Double-heading & 0 & 0 & 6 \\
New meanders & 0 & 31 & 0 \\
Retraction & 0 & 0 & 0 \\
Cutoff & 41 & 11 & 0 \\
Complex change & 10 & 15 & 0 \\
Stable meander & 25 & 15 & 44 \\
Avulsion & 10 & 0 & 0 \\
\hline
\end{tabular}

Table 11

Morphodynamic annual values $\left(10^{3} \mathrm{~m}^{2}\right)$ to each period in reach 3 .

\begin{tabular}{llllll}
\hline Period & $E$ & $D$ & $A P$ & $T$ & $E / D$ \\
\hline $1962-1978$ & 1,49 & 1,65 & 0,08 & 3,16 & 0,90 \\
$1978-1997$ & 0,67 & 1,29 & 0,24 & 2,21 & 0,52 \\
$1997-2008$ & 1,09 & 0,94 & 0,15 & 2,19 & 1,16 \\
\hline
\end{tabular}

$E=$ eroded area, $D=$ deposited area, $A P=$ area formed by both processes, $T=$ total morphodynamics, and $E / D=$ ratio of eroded and deposited areas.
Table 12

Sinuosity and number of bends in reach 3 .

\begin{tabular}{lllll}
\hline & 1962 & 1978 & 1997 & 2008 \\
\hline Sinuosity & 2.62 & 2.04 & 1.53 & 1.66 \\
Number of bends & 28 & 18 & 13 & 13 \\
\hline
\end{tabular}

predominance of aggradation on the floodplain (Table 11). The avulsions strongly modified the morphology of the reach, forming approximately straight segments in areas that previously contained sequences of meanders. In addition, two cutoffs simplified the channel's shape and contributed to aggradation of the floodplain in this period. However, we noted the formation of new meanders, reflecting the strong changes in the previous period.

Changes in the morphometry were also significant between 1978 and 1997 (Fig. 11). These mechanisms (Table 10) reduced the sinuosity by $25.7 \%$, reaching the lowest value (1.52) in 1997 (Table 12). During the last period, 1997-2008, the morphology of the meanders in reach 3 changed little (Fig. 13B; Tables 10-12). In addition, eroded areas predominated over deposition in this period (Table 11) because of development of meanders by migration, growth, and lobing, which is further supported by the $9.5 \%$ increase in sinuosity in 2008 (Table 12).

\subsubsection{Reach 4}

The greatest changes in reach 4 's morphology occurred between 1962 and 1978 (Fig. 14; Tables 13-15). In 1962, the Peixe River in this reach featured compound meanders with high amplitudes, consequently influencing the most radical changes in the channel (Fig. 15). The main change mechanisms in the reach between 1962 and 1978 were cutoffs and migrations (Fig. 15A), which highlights the high degree of fluvial dynamics during this period (Table 13). The aggradation on the floodplain occurred predominantly because of cutoffs (Table 14) and is reflected in the sinuosity, which decreased by $31.4 \%$ to 1.93 (Table 15).

In the subsequent period, 1978-1997, morphological changes in reach 4 continued (Fig. 14; Tables 13-15), but there was a marked change in the mechanisms of channel changes (Table 13) to migration and growth, leading to high activity and near equal $E$ and $D$. The average wavelength continued to be favoured by cutoffs, while the amplitude of the meanders decreased slightly. The continuous decrease in smaller amplitude meanders in reach 4 indicates the

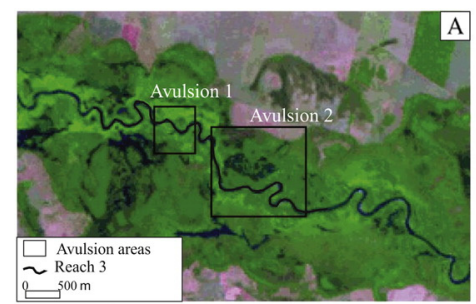

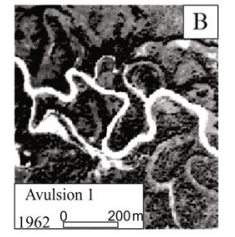
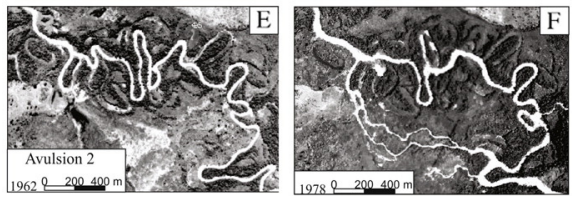
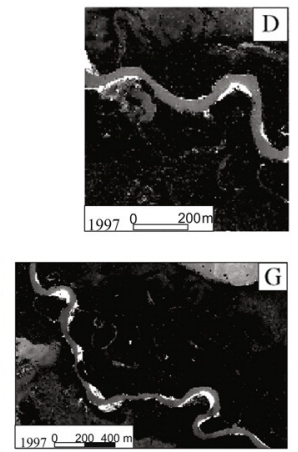

Fig. 12. Avulsions, which were restricted to reach 3 , aided the formation of straight segments. 


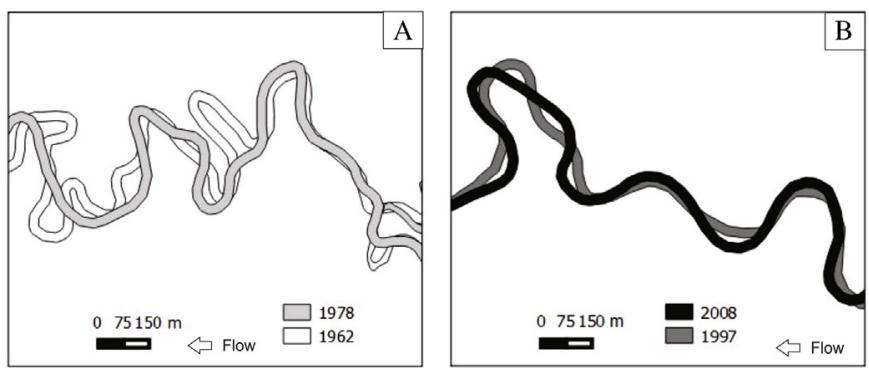

Fig. 13. (A) Cutoffs in reach 3 , which highlight the intensity of the channel changes from 1962 to 1978; and (B) meanders with gradual growth, which suggest the slight restoration of sinuosity from 1997 to 2008.
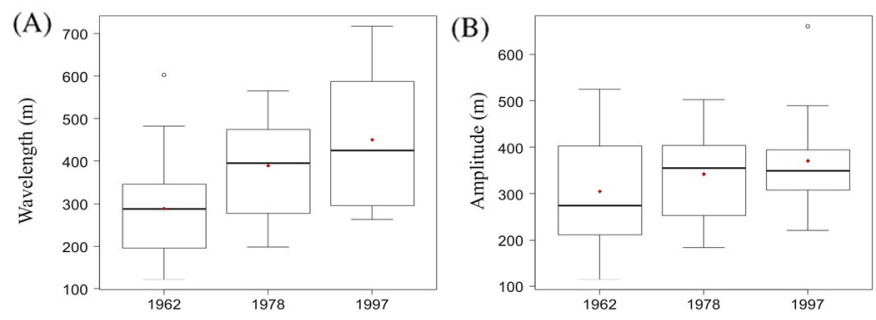

Fig. 14. The variation in wavelength (A) and amplitude (B) in reach 4.

resilience of the larger forms of the channel, which are responsible for the simplified shape and the greater spacing expressed by the wavelength in 1997.

The morphodynamic values during this period varied significantly compared to those in the previous period. The increase in the coefficient between the eroded and deposited areas $(E / D)$ demonstrates this balance in the period. Despite the predominance of mechanisms that increased the sinuosity, such as migration and growth, cutoffs prevailed and slightly decreased sinuosity by $2 \%$ in this period (Table 15).

\subsection{Spatial dynamics}

During the 50-year period the activity rate of the reaches (\% of meanders in the reach with change mechanisms) had marked spatial variability along the channel (Fig. 16). In addition, the statistical analysis points to significant variations in the wavelengths and amplitudes of the meanders, which are presented for each period to elucidate the spatial patterns in the dynamics of the Peixe River.

During the initial period, 1962-1978, the channel's behaviour can be divided between the stability in reach 1 and the high activity of the meanders in the downstream reaches (Fig. 16). In addition, the lowest morphodynamic values occurred in reach 1 . In contrast, intense channel mobility was observed in reaches 2,3 , and 4 , with a percentage of active meanders above $75 \%$ during this period. However, the morphometric

Table 13

Channel change mechanisms that occurred in the meanders (\%) in reach 4.

\begin{tabular}{lll}
\hline Channel change & $1962-1978$ & $1978-1997$ \\
\hline Migration & 15 & 37 \\
Confined migration & 5 & 0 \\
Growth & 5 & 26 \\
Lobing & 0 & 5 \\
Double-heading & 0 & 0 \\
New meanders & 0 & 5 \\
Retraction & 10 & 0 \\
Cutoff & 35 & 11 \\
Complex change & 5 & 11 \\
Stable meanders & 25 & 5 \\
\hline
\end{tabular}

Table 14

Morphodynamic annual values $\left(10^{3} \mathrm{~m}^{2}\right)$ to each period in reach 4 .

\begin{tabular}{llllll}
\hline Period & E & D & AP & T & E/D \\
\hline $1962-1978$ & 1,29 & 2,43 & 0,12 & 3,84 & 0,53 \\
$1978-1997$ & 1,22 & 1,26 & 0,59 & 3,07 & 0,97 \\
\hline
\end{tabular}

$E=$ eroded area, $D=$ deposited area, $A P=$ area formed by both processes, $T=$ total morphodynamics, and $E / D=$ ratio of eroded and deposited areas.

Table 15

Sinuosity and number of bends in reach 4 .

\begin{tabular}{llll}
\hline & 1962 & 1978 & 1997 \\
\hline Sinuosity & 2.71 & 1.93 & 1.87 \\
Number of bends & 32 & 18 & 16 \\
\hline
\end{tabular}

parameters only documented significant variations in reaches 3 and 4 (Table 16).

From 1978 to 1997, the channel exhibited strong activity in all reaches (Fig. 16), despite the different stages of evolution in each reach. In reaches 1,2 , and 3 , cutoffs prompted major changes in the channel's geometry. However, similar and important changes occurred in reaches 2 and 3 that resulted in a simplified and low-sinuosity form of the channel (Table 16). Reach 2 had the highest activity rate, which was associated with large changes in the geometry, as determined by the statistics of the morphometric parameters. The significant variation in the amplitudes of reach 3 's meanders is related to the reorganization of the drainage resulting from the extensive abandonments caused by avulsions.

In contrast to these three reaches, the occurrence of migration in reach 4 , where the channel had already demonstrated the greatest attenuation of sinuosity in 1978, intensified during this period and cutoffs were reduced. These mechanisms did not much alter the geometry of this reach relative to the other reaches. However, higher remobilization of the channel occurred in this reach, with an increase in eroded areas because of migration and growth.

Finally, the behaviour of the reaches from 1997 to 2008 highlighted the spatial variation in the channel changes (Fig. 16). The channel activity was highly dynamic in all the meanders in reach 1 during that period. The great change in the morphology of this reach was supported
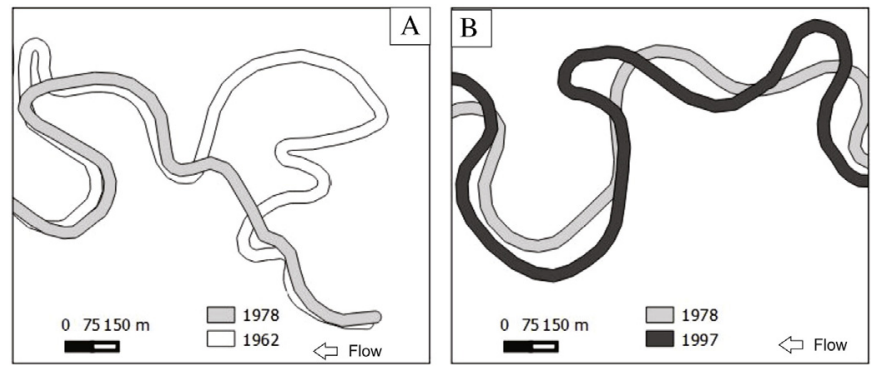

Fig. 15. (A) Cutoffs in reach 4 , which demonstrate the intensity of the changes in the channel from 1962 to 1978; and (B) meanders with gentle growth, which suggest the restoration of sinuosity from 1978 to 1997.

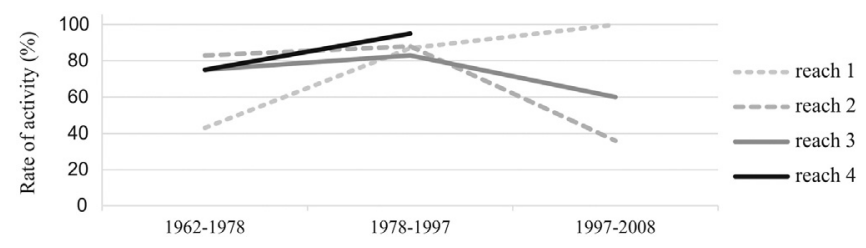

Fig. 16. Spatiotemporal variations in activity rates of the reaches indicated by percentage of meanders with channel change. 
Table 16

Significant changes through statistical analysis in reach morphometry (at $p=0.05$ ).

\begin{tabular}{|c|c|c|c|c|c|c|}
\hline \multirow{2}{*}{ Reach } & \multicolumn{3}{|l|}{ Wavelength } & \multicolumn{3}{|l|}{ Amplitude } \\
\hline & 1962-1978 & 1978-1997 & 1997-2008 & $1962-1978$ & 1978-1997 & 1997-2008 \\
\hline 1 & & & $\mathrm{X}$ & & & $X$ \\
\hline 2 & & $\mathrm{X}$ & & & $\mathrm{X}$ & \\
\hline 3 & & & & $\mathrm{X}$ & $\mathrm{X}$ & \\
\hline 4 & $\mathrm{X}$ & & & & & \\
\hline
\end{tabular}

statistically by significant variations in the wavelengths and amplitudes of the meanders (Table 16). In addition, this reach had the highest morphodynamic values compared to the other reaches, demonstrating the high activity in this period. In contrast, stability predominated in reach 2 , which was characterized by slight changes in the meanders. Preliminary changes and increased activity were more pronounced in reach 3 , which featured more significant erosive morphodynamics than in reach 2.

\subsection{Spatiotemporal variations}

The factor analysis integrates some parameters and reveals the similarities of reaches. In Fig. 17, clusters can be classified as high-, medium, and low-intensity stages of channel dynamics. Group 1 has stages with very slight morphology changes that enhance the temporal contrast between reaches 2 and 3 in relation to reach 1 . Group 2 features medium-intensity changes in the channel morphology, except in reach 2 in 1978-1997. Finally, group 3's stages comprise large changes in morphology that are characterized by heavy depositional activity. This analysis, integrated with other variables, suggests that the channel changes are spatially ordered.

The variation in the lowest sinuosity values between the reaches may improve our understanding of spatiotemporal variations. In reaches 2,3 , and 4 , the lowest sinuosity values occurred in 1997, but specific behaviours produced changes that shifted from downstream to upstream. As a characteristic of the initial adjustment of reach 4, we noted that the migration and growth mechanisms (1962-1978) were common after cutoff clusters (1962-1978). These shifts in the mechanisms are responsible for the transition from depositional to erosive characteristics in the reach. Significant variations in reach 3's morphometric parameters were present in 1962-1978 and extended through the 1978-1997 period. Furthermore, fewer cutoffs were observed in this period.

Despite the higher number of cutoffs that occurred in reach 2 between 1962 and 1978, significant morphometric variations occurred only in the period 1978-1997 owing to the large sizes of the abandoned

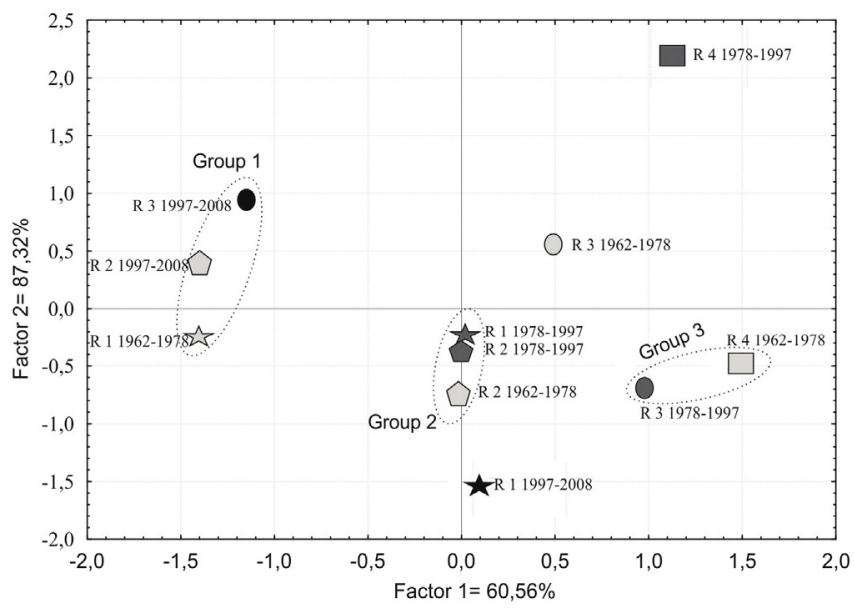

Fig. 17. Factor analysis of the reaches (R) in the respective periods. The marked clusters indicate different stages of fluvial dynamics. meanders. As evidence of the delay in the evolution of this reach compared to reach 3, reach 2 had fewer eroded areas and a lower activity rate compared to reach 3 . In reach 1 , the delay in the channel changes relative to those in the other reaches was more evident, and the reach achieved its most simplified planform only in 2008.

In summary, the morphometric parameters of the reaches illustrated the extensive changes in the channel planform during the study period, and statistical tests detailed the spatial and temporal variations in the Peixe River. The behaviour of the reaches indicated that the changes were initially more intense downstream and progressed upstream in the subsequent periods. The significant variations in the morphometric parameters of the reaches occurred progressively in the following sequence: (i) reaches 3 and 4 between 1962 and 1978, (ii) reach 2 between 1978 and 1997, and (iii) reach 1 between 1997 and 2008.

\section{Discussion}

\subsection{Compound meanders}

The compound meanders with multiple lobes in the Peixe River are equivalent to those described by Hack (1965). Although compound meanders developed between 1907 and 1962, we focused the evaluation on a dramatic reduction in compound meanders during the study period (1962-2008), complementary to studies that documented the development of this type of meander (Brice, 1974; Hooke and Harvey, 1983; Howard and Hemberger, 1991; Seminara et al., 2001; Frothingham and Rhoads, 2003; Kiss and Blanka, 2012; Engel and Rhoads, 2012).

The changes in the compound meanders (20\% of the length of each reach, approximately) are indicative of the adjustment pattern, especially in reaches 1 and 4, the extreme upstream and downstream reaches, respectively. The restricted distribution and evolution of these compound meanders, as noted in the examples in Fig. 18, show the importance of the spatial and temporal variations in the channel's behaviour.

Compound meanders with multiple loops show that the changes in reaches 1 and 4 possessed distinct temporal differences. In reach 4 , most of these compound meanders were summarily eliminated during the period 1962-1978, leaving only a single occurrence that was eliminated in the following period. In contrast, in reach 1 the elimination of these forms only began in 1978-1997 with three cutoffs, followed by the elimination of another two loops by cutoffs in 1997-2008. The change in this type of meander indicates their gradual elimination in reach 1 , and these distinctions between the reaches are indicative of sharp adjustment from downstream to upstream.

\subsection{Main channel change mechanisms}

The high occurrence of channel change mechanisms in the morphology of all the meanders during the 46 years in this study indicated the

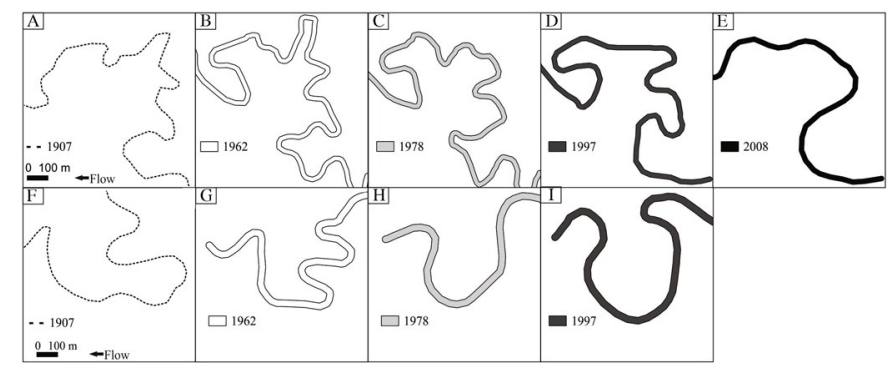

Fig. 18. The channel in reaches 1 (A-E) and 4 (F-I) demonstrated similar change patterns related to the elimination of low-amplitude meanders, leading to a single large meander. Despite the similarity in the channel change mechanisms, the difference in the time scales of the morphologic transformations indicates less resistance in reach 4 's meanders and the more gradual abandonment in reach 1 . 


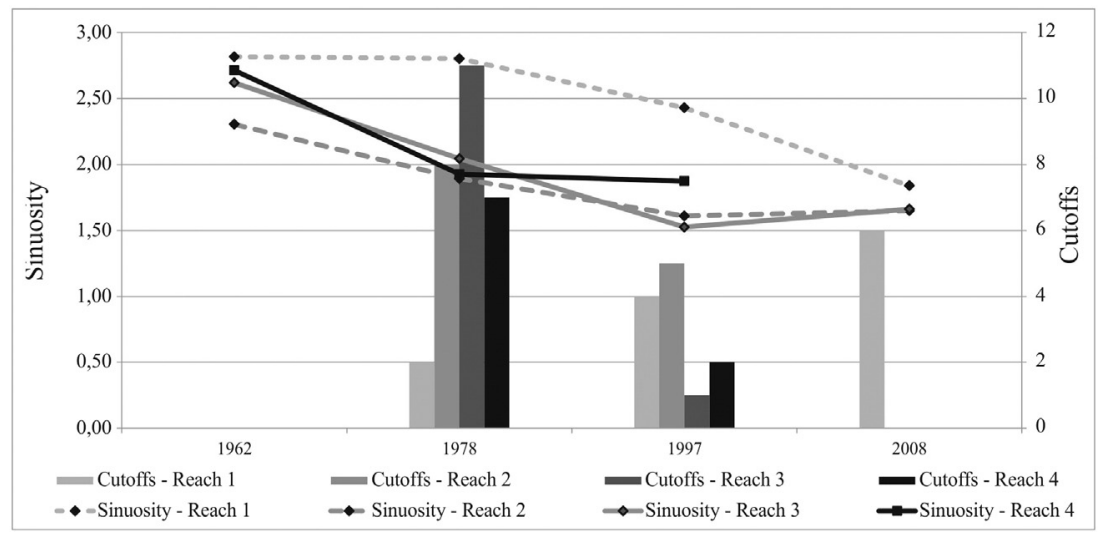

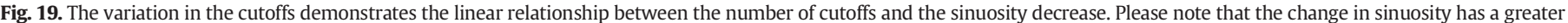
delay toward reach 1 .

remarkable fluvial dynamics in the Peixe River. The temporal dynamics of the number of cutoffs in the reaches highlighted the spatial variations in the channel's behaviour (Fig. 19). The number of cutoffs decreased in reaches 2,3 , and 4 over the study periods; whereas the number of cutoffs progressively increased in reach 1 . Behaviour similar to the cutoff clusters later at the upstream (reach 1 ) matches to the modelling results that indicate a delay in the channel changes upstream (Seminara et al., 2001; Pittaluga et al., 2009).

In addition, a slight decrease in cutoffs downstream was observed over the course of the 46 years, based on the total number of events by reach (Fig. 19). During the same interval, we also noted that the average amplitude of abandoned meanders increased downstream. This relationship between amount of processes and meander size resulted in reaches with similar sinuosity in 2008. The behaviour of the reaches along the Peixe River indicates the decreases in channel sinuosity, however with remarkable spatial-temporal variation of the channel changes, which may be interpreted as possible evidence of progressive fluvial adjustment.

Although cutoffs represent the most common mechanism of sinuosity decrease in meandering rivers (Hooke, 2004; Camporeale et al.,
2008; Constantine and Dunne, 2008), avulsions are able to produce drastic channel changes (Kleinhans et al., 2013). The channel changes in the Peixe River included by restricted avulsions in reach 3, represent spatial variations in meandering patterns (Fig. 12), particularly with respect to certain models of meandering rivers that regard the occurrence of cutoffs only as channel abandonments (e.g., Lancaster and Bras, 2002; Camporeale et al., 2005; Xu et al., 2011). Models that integrate the internal and external characteristics of the river system and incorporate the occurrence of avulsions in the perspective of continuum (e.g., the model of Nicholas, 2013) appear to be more similar to the ephemeral behaviour found in reach 3 in the Peixe River.

\subsection{Channel adjustment pattern}

Channel changes in the Peixe River can be visually observed in the morphology of the reaches (Fig. 20) and confirmed by statistical tests of morphometric parameters. Fluvial adjustments with space-time discontinuity of channel changes are widely known (e.g., Keesstra et al., 2005; Harmar and Clifford, 2006). As discussed by Phillips (2003), the responses of a fluvial system may take multiple modes.

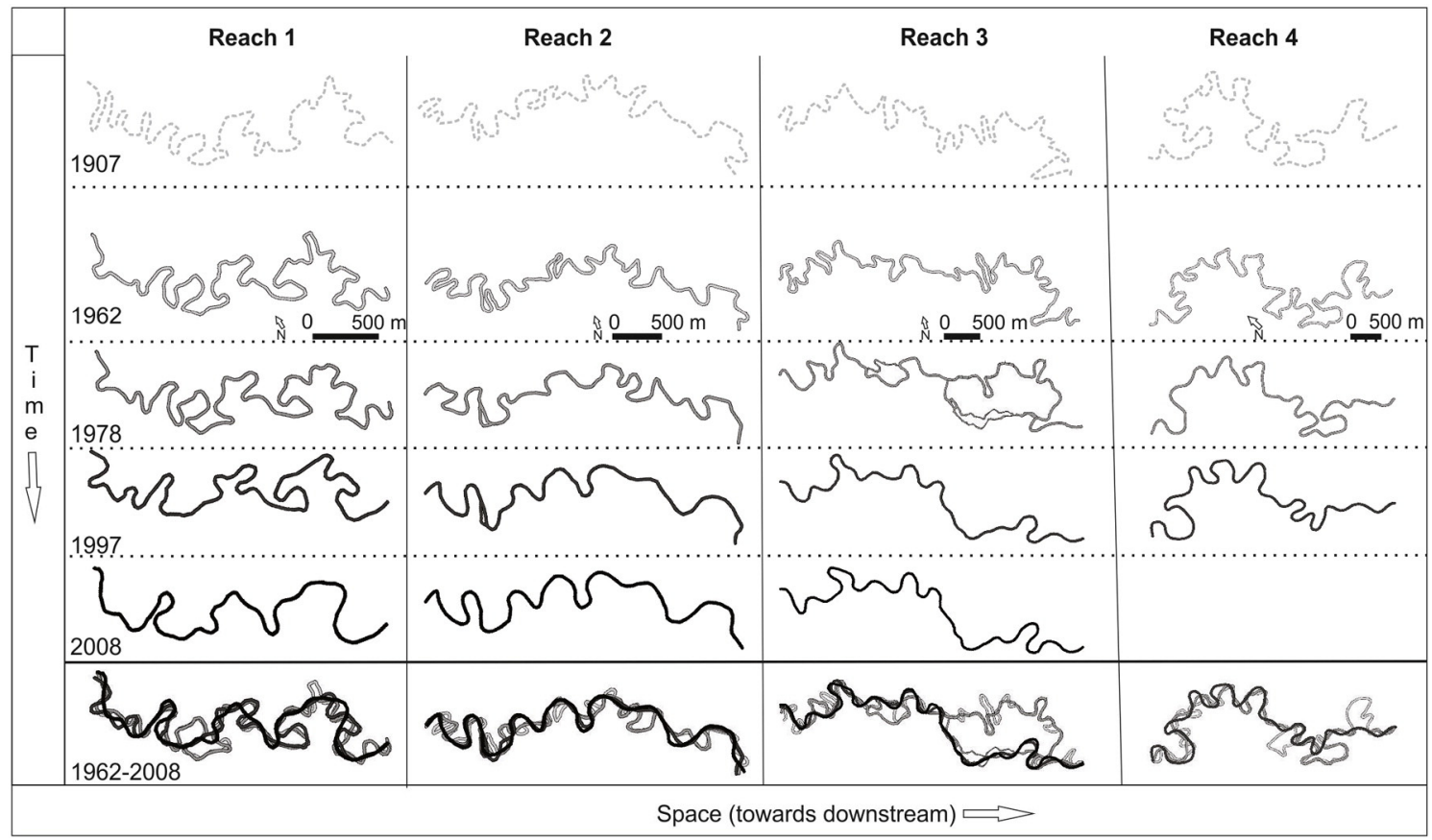

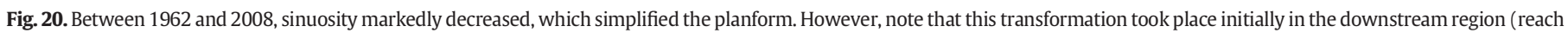
4) and then intensified in the upstream area (reach 1). 
However, cases in which there is evidence of spatial ordering in the channel changes from downstream to upstream, such as observed in the Peixe River, are scarce.

The transformations in the channel morphology initiated similar alterations in the reaches' morphometry during the 46-year period (1962-2008). In 1907 and 1962, the reaches were characterized by the high number of meanders and high sinuosity, whereas in 2008 we observed that the channel had achieved a pattern of gentle curves; marked by a reduction in numbers of meanders and very similar morphology between the reaches (standard deviation of the sinuosity is 0.10). This result also matches the results of Trivellato (2013), who found a sinuosity decrease between 1907 and 1974 in segments of the Peixe River upstream of the studied reaches. These changes in the channel morphology between 1962 and 2008, which encompass all the reaches, are interpreted as the adjustment of the Peixe River to discharge and sediment alterations.

As part of this dynamic, the activity rate of the reaches varied independently of the sinuosity, as it took place during 1962-1978. For instance, we verified that reaches 1 and 4 had high sinuosity in 1962 (2.82 and 2.71, respectively). However, channel changes were insignificant in reach 1 until 1978. In contrast, major morphological channel changes occurred in reach 4 . In the same period, we also observed a strong activity rate and cutoff clusters in reach 3 , even though the sinuosity in 1962 was relatively low in this reach (2.32). These reaches' behaviours differed from the results reported by Guccione (1984) and Hooke (2007), who noted the tendency of the largest declines in sinuosity to occur in reaches with the highest sinuosity levels. Therefore, high sinuosity may not be indicating imminent transformations of channel planform, at least in the scale observed in Peixe River.

\subsection{Causes of fluvial adjustment}

Alternating reaches with high and low river dynamics during all periods and the concomitant regularity of floods suggests that this factor has a secondary role in the changes in meanders. During the analysed period (1962-2008), the reaches' high sinuosity decreased but there was no significant variation in the amount and duration of floods according to the records from 1976 (Fig. 2). This finding does not diminish the role of such events as the main mechanisms of erosion and deposition, which lead to channel changes; but it does indicate that channel changes primarily respond to other dynamic controls on meanders (Hooke, 2007; Gautier et al., 2010).

Establishing the causes of fluvial adjustment has been recognized as a complex task, especially in environments exposed to cumulative impacts (Rinaldi, 2003; Downs et al., 2013; Nelson et al., 2013), such as the catchment of the Peixe River. The formation of the secondary channel observed in reach 1 and the base level rise that occurred in the Paraná River's reservoir correspond to possible influences within restricted time scales. The analysis of reach 1 did not produce evidence that the division of the flow upstream (avulsion) changed the development of meanders. Moreover, there is no evidence of channel changes associated with the downstream reservoir.

Other factors, such as land use changes and the upstream reservoir, represent human factors with potential influence on the Peixe River reaches during the study period. Both factors are suggested to have contributed to the adjustment that occurred in the reaches. In the case of land use, the geomorphic responses to the occupation in the region (such as the formation of gullies on slopes, anthropogenic alluvial fans in the plains, and the disappearance of riffles) indicate significant remobilization of sediment in the channel (Chiarini et al., 1976; CBH-AP, 2008; Trivellato and Perez Filho, 2012). Changes in the rural land use in the catchment potentially produced abundant sediment. For example, cotton and coffee crops were cultivated in deep sandy soils with high erodibility between 1920 and 1960, and one of main reasons for the decline of these crops was caused by soil exhaustion. Moreover, the fast growth of urban areas occurred with inefficient or even absent drainage infrastructure, resulting in extensive erosion in urban areas (CBH-AP, 2008).

The Quatiara reservoir, located upstream of the reaches, may exert effects that influenced the adjustment. The working model of the dam (Fig. 3), with the rare release of sediments, has other documented analogues (Brandt and Swenning, 1999; Batalla and Vericat, 2009; Ma et al., 2012). The reservoir on the Peixe River comprises case 6 of effects classified in the channel downstream of the reservoir, as proposed by Brandt (2000). The reservoir operation model causes a complex change in the hydrosedimentological regime downstream with an erosive/depositional transition phase because of the weekly release from the sediment spillway. The decrease in the sinuosity of the reaches, the elimination of meanders, and responses in the morphologic and morphodynamic parameters suggest the predominance of an erosive effect.

The compound meanders contribute to answering the marked adjustment patterns between 1962 and 2008. Although the formation of compound meanders is associated with growth meanders (Hooke and Harvey, 1983), not all meanders develop this morphological pattern, which leaves the conditions and reasons for the development of this morphology an open question (Hooke, 2013).

The morphology of reaches 1 and 4 in 1907, before the intense land use of the catchment, already featured the presence of compound meanders (Fig. 20). This demonstrates that this type of meander is characteristic of these reaches. Therefore, the development of these forms along the Peixe River cannot be considered the result of human interventions, as has already been argued by Kiss and Blanka (2012), who also incorporated the effects of changes in the precipitation regime.

Based on the flow rate patterns and turbulence near the banks, Engel and Rhoads (2012) considered that compound meanders with two loops tend to evolve over time, instead of assuming a stable configuration. With the changes documented in the compound meanders of the Peixe River, these forms tended to eliminate lobes and therefore evolve toward simplified meanders. This behaviour can be interpreted as a possible indicator of channel adjustment patterns in the meanders.

In general, the decrease in sinuosity represents the fluvial adjustment influenced by human factors, but the spatial-temporal variation in channel changes is caused by the autogenic characteristics of the meandering river. This development in the meandering river suggests an association with intrinsic factors, which might be suitable for the formation and development of compound meanders. Thus, such as in reach 1 , the fluvial adjustment took place later in this reach at the upstream owing to the capacity for compound meander formation. Therefore, the control of the geomorphic thresholds, which govern the bend compound formation, is a primary condition for spatial-temporal adjustment in this meandering river.

\subsection{Consequences of fluvial adjustment}

Morphometric changes may result in a loss of mobility for meandering rivers (Ollero, 2010; Magdaleno and Fernández-Yuste, 2011). In the Peixe River, the geomorphological stability of the channel may represent a significant factor because a decrease in cutoffs would affect lakes and wetlands, which maintain an ecosystem with rich biodiversity (SMAESP, 2010). A decrease in cutoffs would also affect the habitats of species in the Peixe River with the highest risk of extinction, e.g., the largest deer in South America (Mauro et al., 1995; Pinder, 1996; SMAESP, 2010; Andriolo et al., 2013). On the other hand, the marked mobility of the channel can be exemplified by their effect on engineering works, such as the structure of the power transmission network that was affected by fluvial dynamics (Fig. 21).

The behaviour of the channel, based on the reach scale and decadal intervals, may not yet be such as to indicate a loss in fluvial dynamics, despite the significant elimination of meanders. However, the sinuosity tended to decrease in all reaches, with changes oscillating between reaches. From this perspective, despite the progressive reduction in 


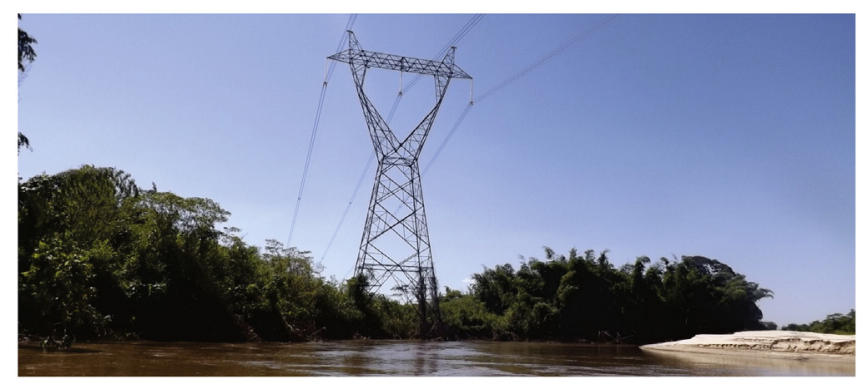

Fig. 21. Energy transmission network that needed to be relocated owing to the intense channel changes in reach 1.

sinuosity, the expressive activity rate (percentage of meanders with changes in morphology) was $60 \%$ greater than over at least two periods in the reaches. Consequently, these changes led to adjustment in the channel, and observations of subsequent periods will determine whether the adjustments imply a loss of fluvial dynamics and the maintenance of the current morphology, i.e., a completion of the adjustment.

\section{Conclusions}

The study of the channel change mechanisms, morphometrics, and morphodynamics of the Peixe River characterizes the spatiotemporal evolution of the river between 1962 and 2008. Prior to this, map evidence suggests comparatively little morphological change in the period 1907-1962. The sharp decrease in sinuosity between 1962 and 2008 in all reaches implies that an adjustment of the channel and meander bend parameters indicate a change to fewer, larger meanders and a simplified planform, accomplished by bend cutoff. Overall, evaluated parameters demonstrated that channel changes took place from downstream to upstream reaches.

The fluvial dynamics of the alluvial segment in which the study reaches are located are subject to cumulative anthropogenic factors. Land use changes and an upstream reservoir are interpreted to be potential causes of the adjustment in the Peixe River observed during the study period. The construction of the reservoir on the Paraná River deserves continuous and detailed monitoring with respect to the morphology of the meanders. The creation of the downstream reservoir on the Paraná River resulted in the loss of a more mobile reach and consequently reduced the wetlands formed by fluvial dynamics, e.g., oxbow lakes.

The compound meanders present prior to major human settlement (in 1907) and the development of these meanders during the decades of human intervention suggests that intrinsic factors regulate the pattern of adjustment. Meanders in certain reaches exhibit the ability to form compound meanders and therefore may achieve higher sinuosity, while other reaches do not have the same capacity. Consequently, channel change mechanisms, such as cutoffs, occur later in reaches dominated by compound meanders. The occurrence of this type of meander even indicates influence on the decay of sinuosity, but the upstream location of these compound meanders is a more important factor. Therefore the morphology of compound meander contributed to the resilience of fluvial adjustment in parts of the channel. From this perspective, compound meanders are a key element in understanding the adjustment of meandering rivers, even in impacted rivers. Overall, a significant simplification of pattern was apparent, with significant increases in meander wavelength.

Meandering channel changes naturally exhibit complex behaviour, and the interpretation of the causes should be treated with caution and should be based on holistic hypotheses, especially in the presence of anthropogenic factors. The adjustment of the Peixe River is related to anthropogenic factors; but the evidence, especially that from the compound meanders, has shown that the pattern of these changes from downstream to upstream is influenced by the intrinsic factors of the meanders' dynamics. Efforts to understand the role of longitudinal variations in the channel gradient and the erodibility of the margins, such as the refinement of the temporal changes in the meanders, should be considered in future studies.

\section{Acknowledgements}

The authors are grateful for financial support by São Paulo State Research Foundation (FAPESP) grants 2011/11208-6 and 2012/00959-3 and for logistic support given by the Peixe River State Park. We also thank the editor Dr. Richard A. Marston and three anonymous reviewers for comments on the earlier version.

\section{Appendix A. Supplementary data}

Supplementary data associated with this article can be found in the online version, at http://dx.doi.org/10.1016/j.geomorph.2016.07.026. These data included the Google map of the most important areas described in this article.

\section{References}

Andriolo, A., Piovezan, U., Costa, M.J.R.P., Torres, H.A., Vogliotti, A., Zerbini, A.N., Duarte, J.M.B., 2013. Severe population decline of marsh deer, Blastocerus dichotomus (Cetartiodactyla : Cervidae), a threatened species, caused by flooding related to a hydroelectric power plant. Zoologia 30 (6), 630-638.

Batalla, R.J., Vericat, D., 2009. Hydrological and sediment transport dynamics of flushing flows : implications for management in large Mediterranean rivers. River Res. Appl. 314, 297-314.

Bollati, I.M., Pellegrini, L., Rinaldi, M., Duci, G., Pelfini, M., 2014. Reach-scale morphological adjustments and stages of channel evolution : the case of the Trebbia River (northern Italy). Geomorphology 221, 176-186.

Brandt, S.A., 2000. Classification of geomorphological effects downstream of dams. Catena 40, 375-401.

Brandt, S.A., Swenning, J., 1999. Sedimentological and geomorphological effects of reservoir flushing : the Cachí reservoir, Costa Rica. Geogr. Ann. 3, 391-407.

Brannstrom, C., Oliveira, A.M.S., 2000. Human modification of stream valleys in the western plateau of São Paulo, Brazil: implications for environmental narratives and management. Land Degrad. Dev. 11, 535-548.

Brice, J.C., 1974. Evolution of meander loops. Geol. Soc. Am. Bull. 85, 581-586.

Câmara, G., Souza, R.C.M., Freitas, U.M., Garrido, J., 1996. SPRING: integrating remote sensing and GIS by object-oriented data modelling. Comput. Graph. 20, 395-403.

Camporeale, C., Perona, P., Porporato, A., Ridolfi, L., 2005. On the long-term behavior of meandering rivers. Water Resour. Res. 41 (12), W12403. http://dx.doi.org/10.1029/ 2005WR004109.

Camporeale, C., Perucca, E., Ridolfi, L., 2008. Significance of cutoff in meandering river dynamics. J. Geophys. Res. 113, F01001.

Cândido, A.J., 1971. Contribuição ao estudo dos meandramentos fluviais. Not. Geomorf. 11, 21-38.

CBH-AP (Comitê das bacias hidrográficas dos rios Aguapeí e Peixe)., 2008. Plano das bacias hidrográficas dos rios Aguapeí e Peixe. (Available in: http://cbhap.org/).

CBH-AP (Comitê das bacias hidrográficas dos rios Aguapeí e Peixe), 1997. Relatório de situação dos recursos hídricos das bacias hidrográficas dos rios Aguapeí e Peixe. Centro Tecnológico da Fundação Paulista (Available in: http://cbhap.org/).

CCG (Comissão Geographica e Geológica do estado de São Paulo)., 1913. Exploração do Rio do Peixe. 2로 ed. Typ. Brazil de Rothschild and Cia, São Paulo (39 pp.).

Chiarini, J.V., Nogueira, F.P., Donzeli, P.L., Barbieri, J.L., Coelho, A.G.S., Ivancko, C.A.M., Bittencourt, I., 1976. Levantamento por fotointerpretação do uso atual das terras do Estado de São Paulo - culturas perenes e temporárias e pastagem. Boletim Tecnico IAC 37.

Constantine, J.A., Dunne, T., 2008. Meander cutoff and the controls on the production of oxbow lakes. Geology 36, 23-26.

Constantine, J.A., Dunne, T., Ahmed, J., Legleiter, C., Lazarus, E.D., 2014. Sediment supply as a driver of river evolution in the Amazon Basin. Nat. Geosci. 1-23.

Development Team, Q.G.I.S., 2016. QGIS Geographic Information System. Open Source Geospatial Foundation Project.

Downs, P.W., Dusterhoff, S.R., Sears, W.A., 2013. Reach-scale channel sensitivity to multiple human activities and natural events : lower Santa Clara River, California, USA. Geomorphology 189, 121-134.

Engel, F.L., Rhoads, B.L., 2012. Geomorphology interaction among mean flow, turbulence, bed morphology, bank failures and channel planform in an evolving compound meander loop. Geomorphology 163-164, 70-83.

Etchebehere, M.L.C., 2000. Terraços neoquaternários no vale do Rio do Peixe, Planalto Ocidental Paulista: implicações estratigráficas e tectônicas (PhD Thesis) Universidade Estadual Paulista, Rio Claro.

Etchebehere, M.L., Saad, A.R., 2003. Fácies e associações de fácies em depósitos neoquaternários de terraço na bacia do rio do Peixe, região Ocidental Paulista. Geociências 22, 5-16.

Fernandes, L.A., Coimbra, A.M., 2000. Revisão estratigráfica da parte oriental da Bacia Bauru (Neocretaceo). Rev. Bras. Geoci. 30, pp. 717-728 
Frothingham, K.M., Rhoads, B.L., 2003. Three-dimensional flow structure and channel change in an asymmetrical compound meander loop, Embarras River, Illinois. Earth Surf. Process. Landf. 28 (6), 625-644.

Gautier, E., Brunstein, D., Vauchel, P., Jouanneau, J.M., Roulet, M., Garcia, C., Guyot, J.L., Castro, M., 2010. Channel and floodplain sediment dynamics in a reach of the tropical meandering Rio Beni (Bolivian Amazonia). Earth Surf. Process. Landf. 35 (15), 1838-1853.

Gilvear, D., Winterbottom, S., Sichingabula, H., 2000. Character of channel planform change and meander development: Luangwa River, Zambia. Earth Surf. Process. Landf. 25 (4), 421-436.

Gregory, K., 2006. The human role in changing river channels. Geomorphology 79, $172-191$.

Guccione, M.J., 1984. Causes of channel variations, Red River, Arkansas. In: Elliott, C.M. (Ed.), River MeanderingProceedings of the Conference Rivers 83. New Orleans, LA. ASCE, New York, pp. 101-112.

Hack, J.T., 1965. Post-glacial drainage evolution and stream geometry in the Ontonagon area, Michigan. U. S. Geol. Surv. Prof. Pap. 504B (40 p.).

Harmar, O.P., Clifford, N.J., 2006. Planform dynamics of the Lower Mississippi River. Earth Surf. Process. Landf. 31 (7), 825-843.

Heitmuller, F.T., 2014. Channel adjustments to historical disturbances along the lower Brazos and Sabine Rivers, south-central USA. Geomorphology 204, 382-398.

Hooke, J.M., 2004. Cutoffs galore!: occurrence and causes of multiple cutoffs on a meandering river. Geomorphology 61, 225-238.

Hooke, J.M., 2007. Complexity, self-organisation and variation in behaviour in meandering rivers. Geomorphology 91, 236-258.

Hooke, J.M., 2013. River Meandering. In: John F. Shroder (Editor-in-chief), Wohl, E. (Volume Editor). Treatise on Geomorphology, Vol 9, Fluvial Geomorphology, San Diego: Academic Press. pp. 260-288.

Hooke, J.M., Harvey, A.M., 1983. Meander changes in relation to bend morphology and secondary flows. In: Collinson, J., Lewin, J. (Eds.), Modern and Ancient Fluvial Systems. International Association of Sediment Special Publication, pp. 121-132.

Hooke, J.M., Yorke, L., 2010. Rates, distributions and mechanisms of change in meander morphology over decadal timescales: River Dane, UK. Earth Surf. Process. Landf. 35 (13), 1601-1614.

Howard, A.D., Hemberger, A.T., 1991. Multivariate characterization of meandering. Geomorphology 4, 161-186.

Keesstra, S.D., van Huissteden, J., Vandenberghe, J., Van Dam, O., de Gier, J., Pleizier, I.D., 2005. Evolution of the morphology of the river Dragonja (SW Slovenia) due to land-use changes. Geomorphology 69, 191-207.

Kiss, T., Blanka, V., 2012. River channel response to climate and human-induced hydrological changes: case study on the meandering Hernád River, Hungary. Geomorphology 175-176, 115-125.

Kleinhans, M.G., Ferguson, R.I., Lane, S.N., Hardy, R.J., 2013. Splitting rivers at their seams: bifurcations and avulsion. Earth Surf. Process. Landf. 38, 47-61. http://dx.doi.org/10. 1002/esp.3268

Lancaster, S.T., Bras, R.L., 2002. A simple model of river meandering and its comparison to natural channels. Hydrol. Process. 16, 1-26.

Ma, Y., Huang, H.Q., Nanson, G.C., Li, Y., Yao, W., 2012. Channel adjustments in response to the operation of large dams : the upper reach of the lower Yellow River. Geomorphology 147-148, 35-48.

Magdaleno, F., Fernández-Yuste, J.A., 2011. Meander dynamics in a changing river corridor. Geomorphology 130, 197-207.

Martins, D.P., Bravard, J., Stevaux, J.C., 2009. Dynamics of water flow and sediments in the Upper Paraná River between Porto Primavera and Itaipu dams, Brazil. Geomorphology 16 (2), 111-118.

Mauro, R.A., Mourão, G.M., Pereira da Silva, M., Coutinho, M.E., Tomas, W.M., Magnusson, W.E. 1995. Influência do habitat na densidade e distribuição de cervo (Blastocerus dichotomus) durante a estação de seca no pantanal mato-grossense. Rev. Bras. Biol. 55 (4), 745-751.

Montanher, O.C., 2013. Ciclos de erosão e sedimentação em bacias hidrográficas urbanas do noroeste paranaense e suas implicações no ajuste de sistemas fluviais. Rev. Bras. Geomorf. 14, 319-325.

Nelson, N.C., Erwin, S.O., Schmidt, J.C., 2013. Spatial and temporal patterns in channel change on the Snake River downstream from Jackson Lake dam, Wyoming. Geomorphology 200, 132-142.
Nicholas, A.P., 2013. Modelling the continuum of river channel patterns. Earth Surf. Process. Landf. 38, 1187-1196. http://dx.doi.org/10.1002/esp.3431.

Ollero, A., 2010. Channel changes and floodplain management in the meandering middle: Ebro River, Spain. Geomorphology 117, 247-260.

Perrota, M.M., Salvador, E.D., Lopes, R.C., D'agostino, L.Z., Peruffo, N., Gomes, S.D., Sachs, L.L.B., Meira, V.T., Lacerda Filho, J.V., 2005. Mapa Geológico de São Paulo, Escala 1: 750.000, SIG. São Paulo, Convênio CPRM/Secretaria de Energia, Recursos Hídricos e Saneamento do Estado de São Paulo.

Phillips, J.D., 2003. Toledo bend reservoir and geomorphic response in the lower Sabine River. River Res. Appl. 159, 137-159.

Pinder, L., 1996. Marsh deer Blastocerus dichotomus population estimate in the Paraná River, Brasil. Biol. Conserv. 75, 87-91.

Pittaluga, M.B., Nobile, G., Seminara, G., 2009. A nonlinear model for river meandering. Water Resour. Res. 45, W04432. http://dx.doi.org/10.1029/2008WR007298.

Rinaldi, M., 2003. Recent channel adjustments in alluvial rivers of Tuscany, central Italy. Earth Surf. Process. Landf. 28 (6), 587-608.

Rocha, P.C., 2010. Indicadores de Alteração Hidrológica no Alto Rio Paraná: Intervenções Humanas e Implicações na Dinâmica do Ambiente Fluvial. Soc. Nat. 22, 191-211.

Ross, J.L.S., Moroz, I.C., 1996. Mapa Geomorfológico do Estado de São Paulo. Rev. Dep. Geogr. 10, 41-56.

Santa'nna Neto, J.L., Tommaselli, J.T.G., 2009. O tempo e o clima de Presidente Prudente FCT/UNESP, Presidente Prudente (78 pp.).

Santos, A.A., 2013. Dinâmica hidrosedimentológica nos rios Aguapeí e Peixe, Oeste Paulista. 2013. Monograph. Universidade Estadual Paulista, Presidente Prudente.

Santos, C.A.M., Nunes, J.O.R., Saens, C.A.T., 2013. Contribuição à análise de proveniência sedimentar pelo método traços de fissão em zircão e influências estruturais para a formação do Planalto Residual de Marília. Rev. Bras. Geomorf. 3, 331-341.

Seminara, G., Zolezzi, G., Tubino, M., Zardi, D., 2001. Downstream and upstream influence in river meandering. Part 2. Planimetric development. J. Fluid Mech. 438, 213-230.

Sherrard, J.J., Erskine, W.D., 1991. Complex response of a sand-bed stream to upstream impoundment. Regul. Rivers 6, 53-70.

SMAESP (Secretaria de Meio Ambiente do Estado de São Paulo)., 2010). Plano de manejo do parque estadual do rio do Peixe. (Disponível em: http://fflorestal.sp.gov.br/ Available in: 12 de fevereiro de 2015).

Souza, J.O.P., Corrêa, A.C.B., 2012. Sistema fluvial e planejamento local no semiárido. Mercartor 11, 149-168.

Souza Filho, E.E., 2009. Evaluation of the Upper Paraná River discharge controlled by reservoirs. Braz. J. Biol. 69, 707-716.

Stølum, H.H., 1996. River meandering as a self-organized process. Science 271, $1710-1713$.

Stølum, H.H., 1998. Planform geometry and dynamics of meandering rivers. Geology 11, 1485-1498.

Trivellato, F.T., 2013. Dinâmica fluvial no canal principal da bacia do rio do Peixe (Planalto Ocidental Paulista): análise comparativa a partir da expedição 1905/1906 realizada pela comissão geográfica e geológica do estado de São Paulo (Master dissertation) Unicamp, Campinas.

Trivellato, F.T., Perez Filho, A., 2012. A bacia do rio do Peixe - planalto ocidental paulista: 90 anos de transformações do uso e ocupações das terras. Rev. Geonorte 3, 656-666.

Winterbottom, S.J., 2000. Medium and short-term channel planform changes on the rivers Tay and Tummel, Scotland. Geomorphology 34, 195-208.

Xu, D., Bai, Y., Ma, J., Tan, Y., 2011. Numerical investigation of long-term planform dynamics and stability of river meandering on fluvial floodplains. Geomorphology 132, 195-207.

Zancopé, M.H.C., Perez Filho, A., 2009. Considerações a respeito das planícies fluviais do rio Mogi-Guaçu. Rev. Bras. Geomorf. 7, 65-71.

Zancopé, M.H.C., Peres Filho, A., Capri Júnior, S., 2009. Anomalias do perfil longitudinal e migração dos meandros do rio Mogi Guaçu. Rev. Bras. Geomorf. 10, 31-42.

Ziliani, L., Surian, N., 2012. Evolutionary trajectory of channel morphology and controlling factors in a large gravel-bed river. Geomorphology 173-174, 104-117. 